\title{
Relational Thinking of Student with Visual Impairment in Solving Mathematical Literacy Problem
}

\author{
Ade Restu Pratama \\ Master Program of Mathematics \\ Education \\ Sebelas Maret University \\ Surakarta, Indonesia \\ Ade.restu@student.uns.ac.id
}

\author{
Dewi Retno Sari Saputro \\ Master Program of Mathematics \\ Education \\ Sebelas Maret University \\ Surakarta, Indonesia
}

\author{
Riyadi \\ Master Program of Mathematics \\ Education \\ Sebelas Maret University \\ Surakarta, Indonesia
}

\begin{abstract}
This study aims to describe the relational thinking process in the student with visual impairment in solving mathematical problems. There are three categories of relational thinking: Establishing Relational Thinking, Consolidating Relational Thinking, and Relational Thinking Thoughts. The subjects of this research are students with vision impairment of low vision categories educated in inclusive school. The problem of mathematical literacy chosen is the literacy problem corresponding to PISA. The approach in this research is qualitative with descriptive research. The student with visual impairment is given problems related to mathematical literacy to determine the relational thinking process. Then the students were interviewed to determine the relational thinking process in solving the mathematical literacy. The results obtained are the relational thinking of student with visual impairment category low vision including into consolidating relational thinking.
\end{abstract}

Keywords - relational thinking; mathematical literacy; student with visual impairment

\section{INTRODUCTION}

The function of the human brain is thinking the problem. Thinking is an activity in which the mind is made to make judgments, solve problems or make decisions on a problem based on the information and experience existing in everyday life [1]. Thinking and problem solving are two things are related because one of the goals of thinking is to solve the problem [2]. While problem-solving is the heart of mathematics [3] [4]. Therefore, learning about mathematics can improve thinking ability [5] [6] [7] [8]. The thinking ability in solving problems can be used to solve problems in daily life more generally [5] [9]. That reason makes mathematics as a compulsory subject is to start from the ground level. The way of thinking of students can be in solving mathematical problems. According to Polya in solving the problem, there are four stages namely (1) understanding the problem; (2) devising a plan; (3) carrying out a plan; (4) looking back [10]. Based on the stages can be identified how is the way of students thinking. By knowing how the students in thinking will facilitate in finding errors in students' understanding of the math material taught. It means that the process of thinking in mathematics should be observed apart from the mathematical content itself. One of thinking method in mathematics as known is relational thinking.

Relational thinking involves sequencing of procedures [11]. Relational thinking is the foundation of algebra [12]. Algebra is known to be an important mathematical study. Algebraic thinking in mathematics can be used to analyze deeper mathematical structures [5]. So that relational thinking can help students in solving math problems. Student relational thinking abilities exist in three categories: The Established Relational Thinking, Consolidating Relational Thinking, and Emerging Relational Thinking [13]. Variations in categories of students' relational thinking skills illustrate the diverse understanding of students in understanding a problem. The different understanding raises different problem solving with each other. The category of good mathematical problems can be practicing to problem-solving in daily life that is mathematical literacy problems [14]

In a modern society during the 21 st century, that humans are not necessarily needed, but also the ability to solve, develop, and integrate knowledge. And adaptability, initiative and selfdirection, social and cross-cultural, productivity and accountability, leadership and responsibility, and information literacy [14] [15]. The ability of the 21st century can be trained through learning mathematical problem-solving. When students learn about the problems of mathematical literacy is expected students' ability in relational thinking in solving problems can increase. Moreover, the problem of mathematical literacy presents a problem in the real world that later in solving it using the mathematical context. Moreover, the problem of mathematical literacy presents a problem in the real world that later in solving it using the mathematical context. Moreover, the problem-solving ability of Indonesian students in real-life problems is low [16]. PISA level 1, 2 and 3, and some students can solve level 4 [17]. This makes the reason that the relational thinking of students in solving the problem of mathematical 
literacy becomes a very important research object. Moreover relational thinking on students who have vision problems.

In the beginning, has been mentioned about the important point in thinking that is processing information. The sense of sight is the main source of information because $80 \%$ of information is obtained through it [18]. How would it be if the students had vision problems?. The information received is certainly no more perfect than students who get complete information from all senses, including the sense of sight. For students with visual impairment, in solving mathematical problems cannot be obtained completely and intact. This makes students with visual impairments need special attention. Students with visual impairment are generally divided into two namely total blind and low vision. Students with totally blind obtain information without involving the sense of sight, whereas students with low vision still use the sense of vision as a source of information but limited [19]. The estimated number of people visually impaired in the world is 285 million, 39 million blind and 246 million having low vision [20]. The number of people with low vision is three times that of the blind and has not yet got the services that suit their needs [21]. This should get a more in-depth study of low vision students. Where they should get the proper educational facilities as per their needs. In Indonesia, school-aged children who experience visual impairment in low vision categories are approximately 39,000 children [22]. Numbers that are not small, although also not much, but need to be considered so that they can also get a decent education, get the right to education in accordance with his rights.

\section{RESEARCH AND METHOD}

\section{A. Relational Thinking}

To understand the meaning of relational thinking in mathematics then must know the meaning of relational thinking in arithmetic. Relational thinking in arithmetic is the initial foundation to delineate the meaning of relational thinking in mathematics. This is because students are said to think relationally if they approach the number of arithmetical relationships to replace computation [23]. Relational thinking in arithmetic as they are at expressions and equations in their entirety, noticing the number of relations between and within these expressions and equations. [24] Then, relational thinking depends on the student being able to see and use the possibility of variations between numbers in a number of sentences [25]. This means that when students think relational in expressing problem-solving in arithmetic, they relate equations in numerical symbols whose variations can be used to solve problems. The important point here lies in the existence of relationships in the form of abstract numerical equations in which the solution involves thinking deductively. So, in general, the notion of relational thinking in mathematical relational thinking as the skill and propensity to use the connections between and the abstract mathematical concepts and specific instances thereof [26]. Furthermore, relational thinking is to think of the context, the knowledge that has been possessed before and the knowledge of mathematical characteristics/structures when facing mathematic problems
[23]. So in this study relational thinking is a skill in making the relationship between and objects with abstract mathematical concepts by utilizing existing information in solving problems.

There are three categorizations of types of relational thinking: Established Relational Thinking, Consolidating Relational Thinking, and Emerging Relational Thinking [13]. There is the description:

\section{TABLE I. CATEGORY OF RELATIONAL THINKING AND ITS} DESCRIPTION

\begin{tabular}{|l|l|}
\hline Categories & \multicolumn{1}{|c|}{ Argument Component } \\
\hline $\begin{array}{l}\text { Established } \\
\text { Relational } \\
\text { Thinking }\end{array}$ & $\begin{array}{l}\text { 1. The student is able to see the } \\
\text { sign equal to (=) as the symbol } \\
\text { of the relation } \\
\text { 2. The student can focus on } \\
\text { expression structur } \\
\text { 3. The student can give } \\
\text { rationality the use of strategy }\end{array}$ \\
\hline $\begin{array}{l}\text { Consolidating } \\
\text { Thelational }\end{array}$ & $\begin{array}{l}\text { Students are able to solve } \\
\text { existing problems, but students } \\
\text { are less able to provide } \\
\text { rationality of strategies used }\end{array}$ \\
\hline $\begin{array}{l}\text { Emerging } \\
\text { Relational } \\
\text { Thinking }\end{array}$ & $\begin{array}{l}\text { Students are still not able to } \\
\text { solve the existing problems } \\
\text { correctly }\end{array}$ \\
\hline
\end{tabular}

Based on the Stephens about the description of the category of relational thinking and understanding of relational thinking, then in this study description of the category of relational thinking, as follows:

\section{1) Established Relational Thinking}

a) The students are able to connect real-world problems to the mathematical structure

b) The students are able to utilize the information provided to solve the problem

c) The student is able to see the sign equal to (=) as the symbol of the relation

d) The student can focus on expression structure

e) The student can give rationality the use of strategy

2) Consolidating Relational Thinking

Students are able to fulfill the Established Relational Thinking category descriptions but consistently have not been able to apply them.

\section{3) Emerging Relational Thinking}

Student have not been able to meet the criterion of category Established Relational Thinking criteria consistenly and cannot solve the problem properly

\section{B. Mathematical Literacy Problem}

PISA defined literacy ability as individual ability to identify, understand, and interpret mathematics in various context which is constructed by using and involving mathematics in daily life [27]. Put simply, mathematics literacy is the knowledge to know and apply basic mathematics in our everyday living [28]. In this study, the problem related to mathematical literacy is the problem that comes from real life and in the solution using mathematical principles. Similar literacy problem about PISA in the form of traditional children game in Indonesia is DAKON. 
These four categories characteristic the range of mathematical content that is central to the discipline and illustrate the broad areas of content used in the test items for PISA 2015: Change and relationships, Space and shape, Quantity, Uncertainty and data [29]. The level of mathematical literacy in PISA consists of levels 1 to 6 [29]. Here is the description:

TABLE II. LEVEL OF MATHEMATICAL LITERACY

\begin{tabular}{|c|c|}
\hline Level & What students can typically do at each level \\
\hline 6 & $\begin{array}{l}\text { At Level } 6 \text { students can conceptualise, generalise, and utilise } \\
\text { information based on their investigations and modelling of } \\
\text { complex problem situations. They can link different information } \\
\text { sources and representations and flexibly translate among them. } \\
\text { Students at this level are capable of advanced mathematical } \\
\text { thinking and reasoning. These students can apply this insight and } \\
\text { understandings along with a mastery of symbolic and formal } \\
\text { mathematical operations and relationships to develop new } \\
\text { approaches and strategies for attacking novel situations. Students } \\
\text { at this level can formulate and precisely communicate their } \\
\text { actions and reflections regarding their findings, interpretations, } \\
\text { arguments, and the appropriateness of these to the original } \\
\text { situations. }\end{array}$ \\
\hline 5 & $\begin{array}{l}\text { At Level } 5 \text { students can develop and work with models for } \\
\text { complex situations, identifying constraints and specifying } \\
\text { assumptions. They can select, compare, and evaluate appropriate } \\
\text { problem solving strategies for dealing with complex problems } \\
\text { related to these models. Students at this level can work } \\
\text { strategically using broad, well-developed thinking and reasoning } \\
\text { skills, appropriate linked representations, symbolic and formal } \\
\text { characterisations, and insight pertaining to these situations. They } \\
\text { can reflect on their actions and formulate and communicate their } \\
\text { interpretations and reasoning. }\end{array}$ \\
\hline 4 & $\begin{array}{l}\text { At Level } 4 \text { students can work effectively with explicit models for } \\
\text { complex concrete situations that may involve constraints or call } \\
\text { for making assumptions. They can select and integrate different } \\
\text { representations, including symbolic ones, linking them directly } \\
\text { to aspects of realworld situations. Students at this level can utilise } \\
\text { well-developed skills and reason flexibly, with some insight, in } \\
\text { these contexts. They can construct and communicate } \\
\text { explanations and arguments based on their interpretations, } \\
\text { arguments, and actions. }\end{array}$ \\
\hline 3 & $\begin{array}{l}\text { At Level } 3 \text { students can execute clearly described procedures, } \\
\text { including those that require sequential decisions. They can select } \\
\text { and apply simple problem solving strategies. Students at this } \\
\text { level can interpret and use representations based on different } \\
\text { information sources and reason directly from them. They can } \\
\text { develop short communications reporting their interpretations, } \\
\text { results and reasoning. }\end{array}$ \\
\hline 2 & $\begin{array}{l}\text { At Level } 2 \text { students can interpret and recognise situations in } \\
\text { contexts that require no more than direct inference. They can } \\
\text { extract relevant information from a single source and make use } \\
\text { of a single representational mode. Students at this level can } \\
\text { employ basic algorithms, formulae, procedures, or conventions. } \\
\text { They are capable of direct reasoning and making literal } \\
\text { interpretations of the results. }\end{array}$ \\
\hline 1 & $\begin{array}{l}\text { At Level } 1 \text { students can answer questions involving familiar } \\
\text { contexts where all relevant information is present and the } \\
\text { questions are clearly defined. They are able to identify } \\
\text { information and to carry out routine procedures according to } \\
\text { direct instructions in explicit situations. They can perform } \\
\text { actions that are obvious and follow immediately from the given } \\
\text { stimuli. }\end{array}$ \\
\hline
\end{tabular}

\section{Students with Visual Impairment}

A visually impaired person who cannot use either partial vision (low vision) or fully (Totally Blind) is caused by damage to the functional, structural and combinations. 30]. Blindness is defined as visual acuity of less than $3 / 60$, or a corresponding visual field loss to less than $10^{\circ}$, in the better eye with the best possible correction [19]. This indicates that the function of the eye cannot work properly. This means that those who fall into this category are not able to use the sense of sight as a source of information. Low vision is defined as visual acuity of less than $6 / 18$ but equal to or better than $3 / 60$, or a corresponding visual field loss to less than $20^{\circ}$, in the better eye with the best possible correction [19]. The definition can be interpreted that those who fall into the category of low vision is still able to use the senses of vision as a source of information but there are limitations. In this study, students with visual impairment of low vision categories were selected from inclusion schools, junior high schools in Surakarta class 7.

\section{RESULTS AND DISCUSSION}

This research uses qualitative approach. The qualitative approach is chosen because qualitative methods are rely on text and image data, have unique steps in data analysis, and draw on diverse designs [31]. The results of this study describe the natural state without any treatment of the subject. [32].

\section{1) Participant}

Subjects in this study was one student who interrupted vision of low vision category. the subject is at level 7 of junior high school in inclusion school, Surakarta. Sample subject by purposive sampling. The selection of Purpose sampling in research subjects was considered very suitable for this study because the determination of the subject is based on conformity with the purpose of this research. and can express the idea well. The selected subject also has the criteria to express ideas and ideas that enable researchers to dig up information related to the purpose of this study.

\section{2) Data Collection and data analysis}

There is a problem about the same mathematical literacy as PISA. The problem raised is a matter of mathematical literacy adapting the Indonesian traditional game of DAKON. The problem is tailored to the knowledge of the research subject at the 7 th level of junior high school. In addition, interviews are used to find out in depth related answers from the subject of research.

The result of solving the problem of mathematical literacy is analyzed to find out the relational thinking process of the students. Furthermore, student interviews to dig more indepth information related answers from students. From the results of interviews and results of student answers analysis will be known categories of relational thinking blind students low vision category.

\section{RESULTS AND DISCUSSION}

Dakon is a traditional game played by Indonesian children. This game uses a game board that has 14 holes and 2 parent holes of a larger size. Played by 2 people. One master hole is located at the end of the board and the other parent hole is located at the 
other end. Between the two parent hole, there are 2 rows which each row contains 7 holes totaling 14 holes. The tool used is using 98 grains of grain or stones. The essence of this game is to obtain seeds/stones as much. Andi and Budi are playing Dakon, after several rounds, there are compositions as follows:

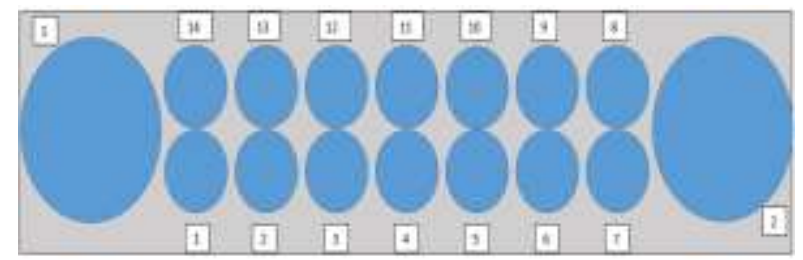

Fig 1. Dakon

$$
\begin{array}{ll}
\begin{array}{c}
\text { Description: } \\
1^{\text {st }} \text { small hole }=1 \text { stone }
\end{array} & \begin{array}{l}
8^{\text {th }} \text { small hole }=13 \\
\text { stones }
\end{array} \\
2^{\text {nd }} \text { small hole }=3 \text { stones } & 10^{\text {th }} \text { small hole }=0 \text { stone } \\
3^{\text {td }} \text { small hole }=7 \text { stone } & 11^{\text {th }} \text { small hole }=0 \text { stone } \\
5^{\text {th }} \text { small hole }=2 \text { stones } & \begin{array}{l}
12^{\text {th }} \text { small hole }=6 \\
\text { stones }
\end{array} \\
6^{\text {th }} \text { small hole }=6 \text { stones } & \begin{array}{l}
14^{\text {th }} \text { small hole }=0 \\
\text { stones }
\end{array} \\
7^{\text {th }} \text { small hole }=3 \text { stones } & 1^{\text {st }} \text { big hole }=19 \text { stones }
\end{array}
$$

a. If the number of stones in the seventh and eighth small holes is equal to the number of sixth and ninth small holes, how many stones in the ninth small hole?

b. If the number of the fourth and eleventh holes is equal to twice the number of stones in the second and the seventh holes, how many rocks in the fourth small hole?

c. If the number of stones in the sixth, seventh and eighth small holes equals twice the number of stones in the thirteenth small hole, how many stones in the thirteenth small hole?

d. What is the approximate number of stones in the second large hole?

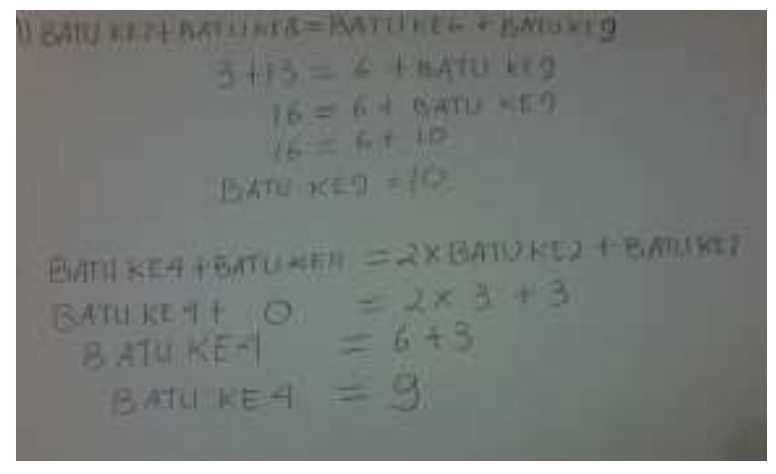

Fig 2. Answer to question poin a and $b$

Based on Figure 2 on student problem-solving point a it appears that the student has understood the problem proposed. The student write BATU KE7 + BATU KE8 = BATU KE6 + BATU KE9 (In English 7th Stone) revealed that students are able to write down problems in mathematical sentences. However, it has not fully used algebraic notation in general.
BATU KE 6, BATU KE7, BATU KE8, and BATU KE9, allegedly as a substitute for the number of stones in each hole. This means that students are able to make the relationship between the problems in the real world that submitted to the math model. Writing Capital letters on the answers because low vision students are easier to see clearly with capital letters and letter enlargement. Algebraic notations revealed by students identify that students understand the use of symbols as a relational matching indicator of relational thinking. The troubleshooting process has also been using mathematical principles correctly. The use of mathematical principles written by students identifies that there has been relational thinking from students in mathematics. This means that students are able to see the overall expression in the mathematical sentences of the problems that have been proposed. The solution given by the students is in accordance with the solution of the problem solving proposed. Analysis of problem-solving results of students will be further explored by analyzing the results of student interviews.

\section{Interview 1}

$\mathrm{R}$ : What do you know from the problem on point a?

S1: the amount of stone, Sir. Stone at number seven hole plus number eight results the same as the number six stone plus number nine. Later look for the number of stones in hole number 9 .

$\mathrm{R}$ : after knowing what to look for what you think?

S2: I write pack like this pack. (Pointing at the answer)

R: Let me explain!

S3: the seventh stone plus the eighth stone is equal to the sixth stone plus the ninth stone (read the answer, Batu ke7 + Batu ke8 = Batu ke6 + Batu ke9). Then substitution the numbers. The stone in the eighth hole is 3 , in the seventh hole 13 , the stone in the sixth hole is 6 .

$\mathrm{R}$ : You mean to write the seventh, eighth, ninth, sixth is what? S4: Let me put it briefly pack. The small number six rocks I wrote the sixth rock (Writing: Batu ke6), small hole stones numbered 7, 8, 9 I wrote the seventh stone, the eighth stone, the ninth stone (Writing: Batu ke7, Batu ke8, Batu ke9).

R: why do you get 10 results?

S5: summed up the first pack. 3 added 13 results $16.16=6+$ Batu ke9. Next, the ninth stone was replaced by 10 let 16 in number.

$\mathrm{R}$ : is there any other way to solve the problem?

S6: I know this way, Sir.

$\mathrm{R}$ : Which way do you use if it has anything to do with the material you got?

S7: yes, Sir. The system of one linear equation.

Based on the results of interview 1 with the students will be analyzed to combine with the results of the analysis of answers from problem-solving students. The result of the S1 interview can be seen that the student is able to understand the proposed problem by knowing the information and the core of the problem (what do you to look for?). Once the student knows what to look for, the student writes the known of the proposed problem (S2). Writing answers to the problems raised have used 
mathematical sentences. By replacing the number of stones in the sixth small hole, the seventh, eighth and ninth with BATU KE6, BATU KE7, BATU KE8, BATU KE9 (S3, S4). This means students have been able to do relational thinking by connecting real-world problems into mathematical form. The process of solving problems is that students substitute the value of each number of known rocks (S3). In this case, the student has successfully utilized the known information from the problem to determine the solution. Next the students do the computing. The computation process corresponds to algebraic operation rules while still looking at symbols as symbols of relations (S4). The last process is to determine the value to be searched by substituting the value whose result is equal to 16 (S5). Students are also able to explain the strategies used in solving the proposed problem.

Based on the analysis of the results of student answers and analysis of student interview results can be said of the relational thinking of students including the category established relational thinking. This can be seen from students being able to connect problems in the real world into mathematical form. Students are able to utilize information to solve problems. Students are able to see symbols equal to as a relation. Students are able to see the overall mathematical expression of the problem. Students are able to explain strategies that are made to solve the problem. Solutions found by students have been in accordance with the solution of the problem posed and the corresponding problemsolving process.

Based on Figure 1 on the results of problem-solving on point $b$ ) it appears that the student has been able to understand the problem posed. But the writing of mathematical sentences is still not true. It appears that students write as in the results of point A That is to replace the number of stones known with BATU KE2, BATU KE4, BATU KE7, and BATU KE11. The discrepancy is evident from the writing 2 x BATU KE2 + BATU KE7. There should be a bracket between BATU KE2 AND BATU KE7 so that the multiplication meaning is not only a multiplier for BATU KE2 but also applies to BATU KE2. This happens because students have not focused on the structure of the mathematical expression. The next process students solve problems in accordance with the principle of algebraic operations. Steps that have not been fit then stepped back to the right direction in algebra operational algebra. It identifies that the relational thinking of the students in the real-world context brought into the mathematical sentence is not so good. This resulted in less precisely in writing the problem into a mathematical form. While in looking at the structure of the expression and see the equation as a symbol of relation to mathematics has passed by students well. Because writing the problem in the mathematical sentence has not been appropriate then the solution of the proposed problem becomes less precise. The error of this answer does not mean that students do not understand the core problem of the problem but rather because the relational thinking process in connecting the problem in the context of the real world into the mathematical sentence is still not so strong. Next will be presented hail interviews with students, then analyzed the results of the interview.
Interview 2

$\mathrm{R}$ : what about the problem points $\mathrm{b}$, what to look for?

S8: looking for the number of stones in the fourth small hole, $\mathrm{Sir}$

R: How to find it??

S9: I write it, Sir.

$\mathrm{R}$ : Let me explain

S10: the fourth stone is added with the eleventh stone equal to twice the second stone plus the seventh stone. (Read the answer). I write that is known then substituted its value, sir. As with point a.

$\mathrm{R}$ : What do you mean to write twice the second stone plus the seventh stone ( 2 x BATU KE2 + BATU KE7)?

S11: I write as you know, Pak (then students read reading about) $\mathrm{R}$ : Is that so true?

S12: I think that's right sir

The result of interview 2 shows that the students have also been able to understand the proposed problem (S8). Students are familiar with what to look for (S8). Then students write with mathematical sentences such as on problem-solving point $\mathrm{A}$ (S9). However, at point B students do not understand the mathematical sentences correctly $(2 \times$ BATU ke $2+$ BATU KE7). This is because the students' understanding of connecting problems in a real-world context into a mathematical sentence has not been so good. Proven given complex problems students have not managed to change the problem posed into mathematical sentences. Whereas in viewing the symbols equal to as a relation and perform computing in accordance with algebraic operations have done the students well. Solutions obtained from students have not been in accordance with the solution of the problem posed. This is because the student has not been good in concealing the real object into the mathematical concept.

Based on the analysis of the results of student answers and analysis of student interview results can be said relational thinking of students including the category of consolidating relational thinking. It is seen that students have not been able to connect real-world problems into mathematical form. The solution found by the students has not been in accordance with the solution of the proposed problem but the problem solving has been in accordance with the mathematical principles. However, Students are able to utilize the information provided to solve the problem. Students are able to see symbols equal to as a relation. Students are able to see the overall mathematical expression in the problem. Students are able to explain strategies that are made to solve the problem. 


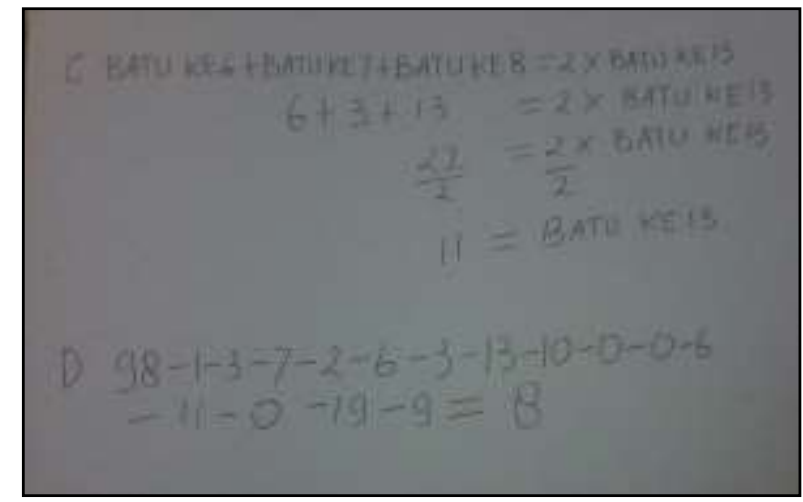

Fig 3. Answer to question point $\mathrm{c}$ and $\mathrm{d}$

Based on Figure 2 on the results of problem-solving on points c) it appears that students have understood the essence of the problem. Students are also able to write mathematical sentences correctly. It means that relational thinking real-world problems into the mathematical context have done the students well. Furthermore, students solve the problem according to the correct computing. Students have understood that equality is a relation and focus on expression in mathematical symbols. The solution of the troubleshooting has been in accordance with the requested solution.

Interview 3

$\mathrm{R}$ : What about the problem of point c. What to look for?

S13: looking for the number of stones in the thirteenth hole, sir. R: How to find it?

S14: I write like point A and Point B, sir.

R: Let me explain!

S15: the stone in the sixth hole plus the seventh stone plus the eighth stone is equal to twice the thirteenth stone. Then put the values. And then counted. The result is found.

The result of interview 3 shows that the students are able to understand the problem. Students are familiar with what to look for. Then students write with mathematical sentences such as on solving the problem points $\mathrm{A}$ and $\mathrm{B}$. This means students are able to do relational thinking by connecting the real world problem into a mathematical form. The process of solving the problem is that students substitute the value of each number of known rocks (S15). In this case, the student has successfully utilized the known information from the problem to determine the solution. Next the students do the computing. The computational process is in line with the rules of algebraic operations while still viewing the symbols as symbols of relations (S15). The last process is to determine the value to be searched by means of value substitution so that the result is the same (S15). Students are also able to explain the strategies used in solving the proposed problem.

Based on the analysis of the results of student answers and analysis of student interview results can be said of the relational thinking of students including the category established relational thinking. This can be seen from students being able to connect problems in the real world into mathematical form. Students are able to utilize information to solve problems.
Students are able to see symbols equal to as a relation. Students are able to see the full extent of mathematical expression in the problem. The solutions found by the students have matched the solution to the problem posed and the problem-solving process.

Based on Figure 2 on the results of problem-solving on points $d$ it appears that the student is able to understand the essence of the problem. Students understand what to look for in the matter. But in writing into the mathematical sentence is not so clear. This is because students do not pay attention to the existing expression structure in mathematics based on the problem posed. The process of troubleshooting is indeed in accordance with the correct computing. Students make calculations to solve problems in detail. The solution obtained does not match the solution of the proposed problem. The inconsistency of the solution corresponds to the solution at point $\mathrm{B}$. The solution to the improper point $\mathrm{B}$ resulted in a less precise solution to this problem. However, students have been able to see the relationship between solutions that students have discovered with the problems at hand.

Interview 4

$\mathrm{R}$ : what about the problem of the last point. What to look for? S16: looking for the number of stones in the second big hole, sir

R: How to find it?

S17: Reduce the number of stones all the way to what is known, sir.

R: Try to explain in more detail.

S18: the number of all the stones is 98 pieces. Then I subtract the number of large perforated stones in unity and the number of all the stones hollowed to one to fourteen, sir.

$\mathrm{R}$ : why do you use that way?

S19: The unknown remains a second big hole, it might be the way it is, sir.

$\mathrm{R}$ : what do you mean?

S20: all holes are known to the number of stones, just a second big hole. So stay minus all, sir

The result of interview 4 shows that the students have also been able to understand the proposed problem. Students are familiar with what to look for. Students solve problems by using the information provided and found to solve the problem (S18). But in terms of writing a mathematical sentence is not correct. The same symbol as a relation is not well understood by the student. Visible students solve the problem without regard to the same symbol as a relation and not paying attention to the overall expression of mathematical dams on the mathematical problem posed. In terms of arguing the rationality of students has not been so good. Looks complicated sentences that students throw to answer questions researchers about how students solve problems.

Based on the analysis of the results of student answers and analysis of student interview results can be said relational thinking of students including the category of consolidating relational thinking. This can be seen from the students have not been able to connect the problem in the real world into a mathematical form. Students are not able to see symbols equal 
to as a relation. Students are not able to see the whole of the mathematical expression in the problem. Students are able to explain strategies that are made to solve the problem. However, Students are able to utilize information to solve problems. The solution found by the students has not been in accordance with the solution of the proposed problem. This is not because students are not at the core of the problem but because the information students find on points $\mathrm{b}$ related to $\mathrm{D}$ point problems is incorrect.

Conclusion for the categorization of relational thinking of students with visual impairment low vision category namely:

1) On the problem of point a, the relational thinking of the students belongs to the category of established relational thinking

2) On the problem of point $b$, the relational thinking of the students belongs to the category of consolidating relational thinking

3) On the problem of point c, the relational thinking of the students belongs to the category of established relational thinking

4) On the problem of point $d$, the relational thinking of the students belongs to the category of consolidating relational thinking

The problems on points a and c are categorized as the same and include the question that easy categories of students tend to fall into the category of established relational thinking. However, looking at the problems on the $b$ and $d$ points that are in the medium category, the relational thinking of the students is included in the consolidating relational thinking category. Based on the above, the researcher classifies the relational thinking of the students into the consolidating relational thinking category. Another reason is that students are not consistent in connecting real-world problems into mathematical sentences. Students have not paid attention to mathematical expressions and symbols equal to as a relation. The inconsistency has resulted in the solution given by the students not yet in accordance with the solution of the proposed problem.

\section{CONCLUTION}

Based on the analysis and discussion can be concluded that students with visual impairment low vision category have the ability to think relational categories Established relational thinking and consolidating relational thinking. However, if studied more deeply students with visual impairment tend to have the ability to think relational thinking consolidating relational thinking category. The reasons are 1) consistently, the student has not been able to connect the problem in connecting the real world into the mathematical sentence, 2) the underprivileged students see the same sign as a relation, 3) the student has not comprehensively seen the expression structure, 3 ) the students, has not been able to provide strategic rationality in solving problems, 4) students are able to utilize the information provided to solve the problem. The relational thinking of the students can be better developed by giving the problem solving an exercise in mathematical literacy problems. the process of relational thinking of students who have been known to be used as materials for improving student learning with vision problems low vision category. so that in the future, students with vision impairment low vision category can develop better. For that, the teacher as an educator must be able to recognize the way of thinking of each student for the progress of the student.

\section{REFERENCES}

[1] M. B. B. Bakry, "The process of thinking among junior high school students in solving HOTS question," IJERE, vol. 4, pp. 138-145, 2015.

[2] R. L. Solso, Cognitive Psychology, Boston: Allyn and Bacon, 1995.

[3] P. R. Halmos, "The heart of mathematics," in The American Mathematical Monthly, vol. 87, pp. 519-524, August 1980.

[4] S. Pimta, S. Tayruakham, and P. Nuangchalerm, "Factor influencing mathematics problem solving ability of sixth grade students," Journal of Social Sciences, vol. 5, pp. 381-385, 2009.

[5] A. Kızıltoprak, "Relational thinking: The bridge between Arithmetic and Algebra," Inter. Elec. Journal of Elementary Education, vol. 10, pp. 131145, 2017.

[6] D. Supriadi, Kreativitas, Kebudayaan dan Perkembangan IPTEK, Bandung: Alfabeta, 1994.

[7] Y. Kristianti, S. Prabawanto, S. Suhendra, "Critical thinking os students throught mathematics learning with ASSURE model assisted by software autograph," IOP Conf. Series Journal of Physics, vol. 895, pp. 1-5, 2017.

[8] Kemendikbud, Regulation of the Minister of Education and Culture Number 59 Year 2013 about Curriculum 2013 SMA/Madrasah Aliyah, Jakarta: Kementerian Pendidikan dan Kebudayaan, 2014.

[9] NCTM, Principles and Standards for School Mathematics, VA: Author, 2000.

[10] G. Polya, How to Solve It, 2nd ed., New Jersey: Princeton Univercity Press, 1973.

[11] T. P. Carpenter, M. L. Franke, Madison, L. Levi, and J. K. Zeringue, "Algebra in elementary schooll: Developing relational thinking", ZDM, vol. 37, pp. 53-59, 2005.

[12] M. Molina and R. Ambrose, "From an operational to a relational conception of the equal sign: Thirds grades' developing Algebraic thinking," Focus on Learning Problems in Mathematics, vol. 30, pp. 6180, 2008.

[13] M. Stephens and X. Wang, "Investigasing some key junctures in relational thinking: A study of year 6 and 7 students from Australia and China," Journal of Mathematics Education Chinese, vol. 17, pp. 36-40, 2008.

[14] K. Stacey, "The PISA view of mathematical literacy in Indonesia," IndoMS-JME, vol. 2, pp. 95-126, 2011.

[15] A. Wijaya, "Students' Information Literacy: A perspective from mathematical literacy," IndoMS-JME, vol. 7, pp. 73- 82, July 2016.

[16] F. Zulkarnain, "The effect of using sentence of question in the beginning of mathematics lesson in primary school," Asian Social Science, vol. 9, pp. 195-204, 2013.

[17] S. I. Edo, Y. Hartono, and R I I Putri, "Investigating secondary school students' difficulties in modeling problems PISA-model level 5 and 6," IndoMS-JME, vol. 4, pp. 41-58, 2013.

[18] E. W. Hill and B. Blasch , Concept Development: Foundations of Orientation and Mobility, New York: American Foundation for the Blind, 1980.

[19] World Health Organization, Vision 2020 the Right to Sight: The Global Initiative for the Elimination of Avoidable Blindness-Action Plan 20062011, 2007.

[20] World Health Organization, Global Data Visual Impairments 2010, 2012.

[21] I. Hosni, Layanan Terpadu Low Vision dalam Mendukung Inklusi. Model Pusat Layanan Terpadu low vision YPWG kerjasama dengan Dinas Pendidikan Jawa Barat dan RS Mata Cicendo. Direktorat Pembinaan Sekolah Luar Biasa, Ditjen Menejemen Dikdasmen, Depdiknas, 2007. 
[22] Infodatin, Situasi Gangguan Penglihatan dan Kebutaan, Jakarta selatan, 2014.

[23] Baiduri, "A relational thinking process of elementery school students with high capability," Journal of Educational and Development Psychology, vol. 4, pp. 24-34, 2014.

[24] V. R. Jacobs, M. L. Franke, T. P. Carpenter, L. Levi, and D. Battey, "Professional development focused on children's Algebraic reasoning in elementary school," Journal for Research in Mathematics Education vol. 38, pp. 258-88, 2007.

[25] M. Stephens, "Describing and Exploring the Power of Relational Thinking," in Identities, Cultures and Learning Spaces, Proceeding of the 29th annual conference of the Mathematics Education Research Group of Australasia, P. Grootenboer, R. Zevenbergen, and M. Chinnappan Eds. Canberra: MERGA. G, 2006, pp. 479-486.

[26] R. D. Wright, "Dissertation: A philosophical approach to relational thinking in mathematics, ProQuest LLC, 2015.
[27] OECD, PISA 2012 Assessment and Analytical Framework: Mathematics, Reading, Science, Problem Solving and Financial Literacy, Paris: OECD Publishing, 2013.

[28] B. Ojose, "Mathematics for literacy: Are we able to put the mathematics we learn into everyday use?," Journal of Mathematics Education, vol. 4, pp. 89-100, 2011.

[29] OECD, PISA 2015 Assessment and Analytical Framework Science, Reading, Mathematic and Financial Literacy. Paris, OECD Publishing, 2016.

[30] L. Berthold, The Visually Handicapped Child in School, London: Constable London, 1974.

[31] J. W. Creswell, Research Design Qualitative, Quantitatve, and Mixed Methods Approaches, California: Sage, 2014.

[32] J. R. Fraenkel, N. E. Wallen, and H. H. Hyun, How to Design and Evaluate Research in Education, New York: McGraw-Hill, 2012. 